\title{
Evaluation of Phylogenetic Relationships of Some Medicinally Important Species of Solanum Based on Seed Protein Profile of SDS-PAGE
}

\author{
Anirban Paul ${ }^{1, *}$, Nirmalya Banerjee ${ }^{2}$ \\ ${ }^{1}$ Department of Botany, Suri Vidyasagar College, Suri, 731101, West Bengal, India \\ ${ }^{2}$ Department of Botany, Visva-Bharati, Santiniketan, 731235, West Bengal, India
}

Received May 18, 2020; Revised June 22, 2020; Accepted July 20, 2020

\begin{abstract}
Cite This Paper in the following Citation Styles
(a): [1] Anirban Paul, Nirmalya Banerjee, "Evaluation of Phylogenetic Relationships of Some Medicinally Important Species of Solanum Based on Seed Protein Profile of SDS-PAGE," Advances in Zoology and Botany, Vol. 8, No. 5, pp. 439 - 446, 2020. DOI: 10.13189/azb.2020.080508.
\end{abstract}

(b): Anirban Paul, Nirmalya Banerjee (2020). Evaluation of Phylogenetic Relationships of Some Medicinally Important Species of Solanum Based on Seed Protein Profile of SDS-PAGE. Advances in Zoology and Botany, 8(5), 439 - 446. DOI: 10.13189/azb.2020.080508.

Copyright $\odot 2020$ by authors, all rights reserved. Authors agree that this article remains permanently open access under the terms of the Creative Commons Attribution License 4.0 International License

Abstract Total amount of soluble seed protein along with its protein profile of nine species of Solanum was investigated through SDS-PAGE. $S$. nigrum and $S$. macranthum contain maximum and minimum amount of total soluble seed protein per gm of tissue respectively. A dendrogram based on Jaccard's similarity index and also on the basis of presence and absence of peptide bands revealed two major clusters- upper cluster (UC) and lower cluster (LC). Both the clusters are again sub-divided in two sub-clusters like UC1, UC2 and LC1, LC2. S. nigrum being evolutionary more closely $(91 \%)$ related to $S$. villosum than $S$. americanum, has been placed in UC1 while $S$. americanum along with $S$. sisymbriifolium, $S$. macranthum and $S$. torvum are placed within UC2. S. indicum and $S$. erianthum showed close resemblance and are placed in LC1 while LC2 contains only $S$. xanthocarpum, which shows least similarity with other studied species of Solanum and thus occupies a distinct place on the dendrogram. Based on these results, the genus Solanum can be divided into two sub genera and the distribution pattern of these species in the two sub genera does not corroborate with the conventional classification. The present study thus provides useful information for the identification of the taxa, their relationship and delimitation of their taxonomic status. So, this omega taxonomical approach may be very much beneficial for future proteomics study.

Keywords Dendrogram, SDS-PAGE, Seed Protein,
Solanum, Sub Genera

\section{Introduction}

Solanum is one of the most economically valuable genera among the 98 genera of 'nightshade' family Solanaceae; which contains approximately 2700 species [1]. Members of this genus are distributed throughout the world, especially in tropical and worm temperate regions, among which largest sub-genus Leptostemonum or 'spinous Solanum' are predominant in India wildly [2]. The genus is not only important for its food value but also equally valuable for its pharmaceutical demands. Several major cultivated crops of Solanum such as S. tuberosum L. (potato), S. melongena L. (eggplant), S. lycopersicum (tomato), S. muricatum Aiton (pepino) etc. are cultivated throughout the world and they provide lots of food security in most of the countries of developing world [2].

More than hundreds of pharmaceutically important alkaloids are found in different wild and cultivated species of Solanum such as solasodine, solasonine, solamargine, solanidine etc. Beside alkaloids sterols, saponins, flavonoids, fatty acids, amino acids, glycosides etc. are also present among the members of Solanum [3]. That is why most of the species are used as analgesic, antinarcotics, 
emollient, diuretic, tonic, laxative, anticancer, antiulcer and also in different types of neuro-vegetative disorders [2-10].

This genus has very rich species diversity among angiosperms [11,12]. However, Solanum has a paradoxical and confusing taxonomy; though it shows much more uniformity in external appearance, it exhibits some contradictory external diversified morphology $[2,9,10,13,14]$. The exact calculations of divergence times of the genus Solanum is problematic, due to lack of fossil evidence. Many earlier workers failed to construct exact phylogenetic tree of the species of Solanum based on different morphological parameters associated with the taxon, which has led too much of the taxonomic confusion among the species $[2,9,10]$.

To investigate probable phylogenetic relationship among the species of Solanum, genetic diversity study may be a powerful tool which has a consistent role during the course of natural evolution. Genetic diversity refers to any variation in the nucleotides, genes, chromosomes or genomes of the organism. Proteins are relatively direct gene products, because a particular protein is synthesized via translation of a specific messenger RNA, which was the transcript product of a particular gene. So, if any variation in expression of protein profile is observed, it may be stated that genetic configuration of that organism has been altered $[2,9,15]$. These proteins are the characteristic raw materials for the anatomical and physiological development of an organism.

The aim of present study was to determine interspecific genetic diversity among nine selected species of wild non-tuberous Solanum that are medicinally important as well as morphologically diversified; using total soluble seed protein profile as a dominant biochemical marker through SDS-PAGE analysis. The results of this study may provide valuable information not only to plant breeders but also to taxonomists in establishing phylogenetic relationships among wild non-tuberous Solanum species.

\section{Materials and Methods}

The selected species of Solanum are Solanum nigrum L., Solanum americanum Mill., Solanum villosum Mill., Solanum torvum Sw., Solanum xanthocarpum Schard. and Wendl., Solanum sisymbriifolium Lam., Solanum macranthum Dunal, Solanum indicum L. and Solanum erianthum D. Don. These species are collected from in and around Santiniketan, Hazaribag and Assam regions. The mature seeds of collected species are sun dried, stored in a desiccator for extraction of seed proteins.

\subsection{Isolation of Seed Proteins}

Total seed protein of each species was extracted from $0.01 \mathrm{~g}$ of seed flour using $400 \mu \mathrm{l}$ of extraction buffer that contained $0.5 \mathrm{M}$ Tris- $\mathrm{HCl}, 0.01 \mathrm{M} \mathrm{MgCl}_{2}, 18 \%$ (w/v) sucrose and $40 \mathrm{mM}$-Mercaptoethnol having pH6.8. Crushed seed samples were thoroughly mixed with buffer by vortexing, transferred to $1.5 \mathrm{ml}$ eppendorf tubes and the extracted proteins were separated by centrifuging at 10000 rpm for $15 \mathrm{~min}$ and the supernatant was collected and stored at $4^{\circ} \mathrm{C}$ as a protein stock for protein analysis. Total soluble seed protein was estimated following the method of Bradford [16].

\subsection{SDS-PAGE Analysis}

Electrophoresis was carried out in a discontinuous sodium dodesyl sulphate polyacrylamide gel electrophoresis (SDS-PAGE) system of Laemmli [17] using $12 \%$ acrylamide gel. A total volume of $10 \mu \mathrm{l}$ protein extract solution was loaded into each well and electrophoresis was carried out at 100 volts until the tracking dye bromophenol blue reached at the bottom of the gel. The gel was stained in the staining solution containing $44 \%$ methanol, $6 \%$ acetic acid, $500 \mathrm{ml}$ double distilled water and $2.25 \mathrm{~g}$ of Comassie Brilliant Blue R-250 for 45 minutes, followed by destaining done in a solution containing 20\% methanol, $5 \%$ acetic acid and $750 \mathrm{ml}$ of double distilled water until the background colour of gel disappeared and protein bands became clearly visible. Banding profile was photographed in gel documentation system manufactured by Perkin Elmer.

\subsection{Data Analysis}

Banding patterns of seed proteins of SDS-PAGE were analyzed and designated into specific types depending on the mobility of the bands. Interspecific comparisons were made by computing the Jaccard's similarity index (S.I.) values between any two selected species based on the presence (1) and absence (0) of polypeptide bands, using the formula, S.I.= Number of similar bands / Number of similar bands + Number of dissimilar bands. Hierarchical clustering or dendrogram was constructed based on the similarity index table using Word's method. The computer software SPSS vs 16 was used for this purpose. Relative mobility (Rf) value of each polypeptide band was determined by using the formula, $\mathrm{Rf}=$ distance migrated by proteins / distance migrated by tracking dye. The molecular weights of the dissociated polypeptides were calibrated through standard curve by using a mixture of standard broad range PMW-B protein markers from Genei, which include myosin (205 KDa), phosphorylase b (97.4 $\mathrm{KDa})$, bovine serum albumin (66 KDa), ovalbumin (43 $\mathrm{KDa})$, carbonic anhydrase (29 KDa), soyabean trypsin inhibitor (20.1 KDa), lysozyme (14.3 KDa), aprotinin (6.5 $\mathrm{KDa})$ and insulin (3 KDa).

\section{Results}

Great variation was observed among the nine selected 
species of Solanum in respect of total amount of soluble seed protein content per gram of seed. The amount of soluble seed protein ranges from $3.78 \pm 0.12$ to $8.67 \pm 0.06$ $\mathrm{mg} / \mathrm{g}$ tissue and Solanum nigrum possesses highest and Solanum macranthum contains lowest amount of soluble seed protein (Table 1).

Figure 1 shows the SDS-PAGE polypeptide band patterns of soluble seed proteins of selected non-tuberous species of Solanum. A total of 40 major polypeptide bands of different sizes were resolved in nine selected species after SDS-PAGE of total soluble seed proteins. The number of polypeptide bands varies from 3 to 6 among the selected species of Solanum. S. xanthocarpum and $S$. villosum exhibited a greater number of bands (6); and least number of bands (3) were observed in S. sisymbriifolium and $S$. indicum.

Table 1. Amount of total soluble seed proteins of selected species of Solanum

\begin{tabular}{|c|c|c|}
\hline $\begin{array}{c}\text { Sl. } \\
\text { No. }\end{array}$ & $\begin{array}{c}\text { Name of the species of } \\
\text { Solanum }\end{array}$ & $\begin{array}{c}\text { Total amount of soluble } \\
\text { seed proteins } \\
\text { (mg/g tissue) }\end{array}$ \\
\hline 1. & S. nigrum & $8.67 \pm 0.06$ \\
\hline 2. & S. americanum & $8.5 \pm 0.09$ \\
\hline 3. & S. villosum & $8.13 \pm 0.02$ \\
\hline 4. & S. torvum & $5.04 \pm 0.08$ \\
\hline 5. & S. xanthocarpum & $6.71 \pm 0.09$ \\
\hline 6. & S. sisymbriifolium & $5.3 \pm 0.13$ \\
\hline 7. & S. macranthum & $3.78 \pm 0.12$ \\
\hline 8. & S. indicum & $3.97 \pm 0.11$ \\
\hline 9. & S. erianthum & $6.45 \pm 0.12$ \\
\hline
\end{tabular}

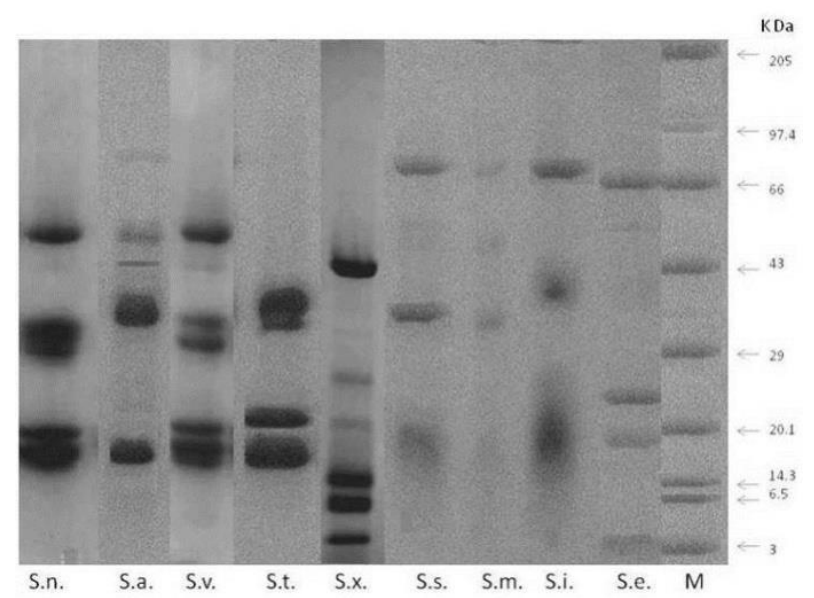

Figure 1. Seed protein profile of SDS-PAGE of nine selected species of Solanum, where S.n.=S. nigrum, S.a.=S. americanum, S.v.=S. villosum, S.t. $=S$. torvum, S.x.=S. xanthocarpum, S.s.= S. sisymbriifolium, S.m. $=S$. macranthum, S.i.=S. indicum and S.e.=S. erianthum; $\mathrm{M}=$ Molecular marker

Molecular weight of each polypeptide band was calculated using standard curve. A total of 19 polypeptide bands of different molecular weight (Table 2) was observed, which ranged from $3.2 \mathrm{KDa}$ to $76.5 \mathrm{KDa}$. Polypeptide $(76.5 \mathrm{KDa}$ ) band of highest molecular weight was observed in four species viz. S. americanum, $S$. sisymbriifolium, S. macranthum and S. indicum. However, S. xanthocarpum shows lowest molecular weight polypeptide (3.2 KDa) band. A specific polypeptide band of $15 \mathrm{KDa}$ was constantly present in six species viz. $S$. nigrum, $S$. americanum, $S$. villosum, $S$. torvum, $S$. sisymbriifolium and $S$. macranthum. Similarly, 33.3 KDa polypeptide band is also common in five species- $S$. nigrum, $S$. americanum, $S$. villosum, $S$. torvum and $S$. sisymbriifolium. This indicates that these two polypeptide bands (33.3 and $15 \mathrm{KDa}$ ) are dominating and they are the major bands among these five species except $S$. macranthum.

Similarity indices (Table 3) were computed based on SDS-PAGE protein profile of selected species of Solanum. Maximum similarity (91\%) is found between S. nigrum and $S$. villosum. Based on SDS-PAGE seed protein profile it is observed that $S$. americanum, $S$. torvum, $S$. sisymbriifolium and S.macranthum do not shown any similarity with $S$. erianthum. Similarly, $S$. nigrum, $S$. sisymbriifolium, $S$. macranthum, $S$. indicum and $S$. erianthum exhibited no similarity with $S$. xanthocarpum. Any similarity is also not found between $S$. indicum and $S$. torvum. Based on similarity indices it may be clearly stated that $S$. xanthocarpum is a species which exhibited least similarity with rest of the species of Solanum. From the similarity indices table (Table 3 ) it is also clearly evident that S. sisymbriifolium and S. americanum exhibited $75 \%$ similarity, indicating that those are evolutionary closely related species. Similarly, it is also commented that $S$. macranthum is more closely related to $S$. sisymbriifolium (0.57 S.I.) than $S$. torvum (0.25 S.I.). The interrelationship of $S$. americanum, $S$. nigrum and $S$. villosum is very important for deciding their proper taxonomic status. Based on the present study, it is also observed that, similarity indices between $S$. nigrum and S. villosum; $S$. americanum and $S$. villosum; $S$. nigrum and $S$. americanum are $0.91,0.73$ and 0.60 respectively. Thus, it can be clearly concluded that $S$. nigrum is very closely related to $S$. villosum than $S$. americanum and it is also evident that $S$. americanum is more distantly related to $S$. nigrum than $S$. villosum particularly from evolutionary point of view.

Based on the similarity indices values, a hierarchical clustering or dendrogram (Figure 2) showing interspecific relationships was obtained using square Euclidean distance interval. This dendrogram shows two main clustered groups- Upper cluster (UC) and Lower cluster (LC). UC comprises of six species ( $S$. nigrum, S. americanum, $S$. villosum, S. sisymbriifolium, $S$. macranthum and $S$. torvum). UC is further sub-divided into two sub-clusters- UC1 and UC2. S. nigrum and S. villosum are closely related and placed at UC1 cluster. But $S$. americanum is distantly related to both the species. Therefore, S. americanum is placed in the UC2 cluster along with $S$. sisymbriifolium, $S$. macranthum and $S$. torvum. From the dendrogram it may be predicted that within the cluster UC2, S. amaricanum is more closely related to $S$. sisymbriifolium than $S$. 
macranthum and obviously from $S$. torvum. LC comprises of three species ( $S$. indicum, $S$. erianthum and $S$. xanthocarpum). LC is also sub-divided into two sub-clusters- LC1 and LC2. S. indicum and S. erianthum show $28 \%$ similarity and placed in LC1 cluster; and LC2 is represented only by $S$. xanthocarpum, which shows least or no similarity with other species of Solanum and thus occupies a distinct place as revealed in the dendrogram.

Table 2. Molecular weight, Rf value of total soluble seed protein profile of SDS-PAGE of selected species of Solanum; where S.n.=S. nigrum, S.a. =S. americanum, S.v. $=S$. villosum, S.t. $=S$. torvum, S.x. $=S$. xanthocarpum, S.s. $=$ S. sisymbriifolium, S.m. $=S$. macranthum, S.i. $=S$. indicum and S.e. $=S$. erianthum; $\mathrm{M}=$ Molecular weight $(\mathrm{KDa})$ of protein band and $\mathrm{Rf}=$ Relative mobility value of protein band

\begin{tabular}{|c|c|c|c|c|c|c|c|c|c|c|c|c|c|c|c|c|c|c|}
\hline \multirow{2}{*}{$\begin{array}{l}\text { Sl. } \\
\text { No. }\end{array}$} & \multicolumn{2}{|c|}{ S.n. } & \multicolumn{2}{|c|}{ S.a. } & \multicolumn{2}{|c|}{ S.v. } & \multicolumn{2}{|c|}{ S.t. } & \multicolumn{2}{|c|}{ S.x. } & \multicolumn{2}{|c|}{ S.s. } & \multicolumn{2}{|c|}{ S.m. } & \multicolumn{2}{|c|}{ S.i. } & \multicolumn{2}{|c|}{ S.e. } \\
\hline & $\mathrm{M}$ & $\mathrm{Rf}$ & M & $\mathrm{Rf}$ & M & $\mathrm{Rf}$ & M & $\mathrm{Rf}$ & M & $\mathrm{Rf}$ & $\mathrm{M}$ & $\mathrm{Rf}$ & M & $\mathrm{Rf}$ & M & $\mathrm{Rf}$ & M & $\mathrm{Rf}$ \\
\hline 1 & - & - & 76.5 & 0.23 & - & - & - & - & - & - & 76.5 & 0.23 & 76.5 & 0.23 & 76.5 & 0.23 & - & - \\
\hline 2 & - & - & - & - & - & - & - & - & - & - & - & - & - & - & - & - & 66 & 0.28 \\
\hline 3 & 52.35 & 0.37 & 52.35 & 0.37 & 52.35 & 0.37 & - & - & - & - & - & - & - & - & - & - & - & - \\
\hline 4 & - & - & - & - & - & - & - & - & - & - & - & - & 49.05 & 0.39 & - & - & - & - \\
\hline 5 & - & - & 42.9 & 0.43 & 42.9 & 0.43 & - & - & 42.9 & 0.43 & - & - & - & - & - & - & - & - \\
\hline 6 & - & - & - & - & - & - & - & - & - & - & - & - & - & - & 38.4 & 0.48 & - & - \\
\hline 7 & - & - & - & - & - & - & 35.85 & 0.51 & - & - & - & - & - & - & - & - & - & - \\
\hline 8 & 33.3 & 0.54 & 33.3 & 0.54 & 33.3 & 0.54 & 33.3 & 0.54 & - & - & 33.3 & 0.54 & - & - & - & - & - & - \\
\hline 9 & - & - & - & - & - & - & - & - & - & - & - & - & 32.4 & 0.55 & - & - & - & - \\
\hline 10 & 30.3 & 0.58 & - & - & 30.3 & 0.58 & - & - & - & - & - & - & - & - & - & - & - & - \\
\hline 11 & - & - & - & - & - & - & - & - & 25.05 & 0.65 & - & - & - & - & - & - & - & - \\
\hline 12 & - & - & - & - & - & - & - & - & - & - & - & - & - & - & - & - & 23.1 & 0.69 \\
\hline 13 & - & - & - & - & - & - & 20.7 & 0.72 & 20.7 & 0.72 & - & - & - & - & - & - & - & - \\
\hline 14 & 17.25 & 0.75 & - & - & 17.25 & 0.75 & - & - & - & - & - & - & - & - & 17.25 & 0.75 & 17.25 & 0.75 \\
\hline 15 & 15 & 0.79 & 15 & 0.79 & 15 & 0.79 & 15 & 0.79 & - & - & 15 & 0.79 & 15 & 0.79 & - & - & - & - \\
\hline 16 & - & - & - & - & - & - & - & - & 12 & 0.84 & - & - & - & - & - & - & - & - \\
\hline 17 & - & - & - & - & - & - & - & - & 5.25 & 0.89 & - & - & - & - & - & - & - & - \\
\hline 18 & - & - & - & - & - & - & - & - & - & - & - & - & - & - & - & - & 3.3 & 0.94 \\
\hline 19 & - & - & - & - & - & - & - & - & 3.2 & 0.95 & - & - & - & - & - & - & - & - \\
\hline
\end{tabular}

Table 3. Jaccard's Similarity index of selected species of Solanum based on seed protein profile study, where S.n.=S. nigrum, S.a. $=S$. americanum, S.v. $=$ S. villosum, S.t. $=$ S. torvum, S.x. $=$ S. xanthocarpum, S.s. $=$ S. sisymbriifolium, S.m. $=$ S. macranthum, S.i. $=S$. indicum and S.e. $=S$. erianthum

\begin{tabular}{|c|c|c|c|c|c|c|c|c|c|}
\hline $\begin{array}{l}\text { Species } \\
\text { name }\end{array}$ & S.n. & S.a. & S.v. & S.t. & $S x$ & S.s. & S.m. & $S . i$ & S.e. \\
\hline S.n. & 1.00 & & & & & & & & \\
\hline S.a. & 0.60 & 1.00 & & & & & & & \\
\hline S.v. & 0.91 & 0.73 & 1.00 & & & & & & \\
\hline S.t. & 0.44 & 0.44 & 0.40 & 1.00 & & & & & \\
\hline$S x$ & 0.00 & 0.18 & 0.17 & 0.20 & 1.00 & & & & \\
\hline$S . s$. & 0.50 & 0.75 & 0.44 & 0.57 & 0.00 & 1.00 & & & \\
\hline S.m. & 0.22 & 0.44 & 0.20 & 0.25 & 0.00 & 0.57 & 1.00 & & \\
\hline$S . i$ & 0.25 & 0.25 & 0.22 & 0.00 & 0.00 & 0.33 & 0.28 & 1.00 & \\
\hline S.e. & 0.22 & 0.00 & 0.20 & 0.00 & 0.00 & 0.00 & 0.00 & 0.28 & 1.00 \\
\hline
\end{tabular}




\section{Discussion}

Solanum is a taxonomical paradox, exhibiting both uniformity and extreme diversity in its morphology [13]. Hence, morphological markers as used in the past are insufficient for their correct and proper identification and placement in taxonomical group [2,9,10]. Various classical, experimental and numerical studies have demonstrated that, this complexity can be attributed to a number of causes such as phenotypic plasticity and genetic variation [18,19]. A high level of genetic polymorphism has been detected among the non-tuberous members of Solanum. Despite their morphological similarity, diversity was exhibited by the extensive polymorphism at the DNA and protein levels. Proteins are the direct gene products, i.e. they are generated from the transcriptionally active parts of DNA, called genes. Thus, protein profile is in general regarded as the active and direct reflection of genomic configuration. The advantage behind the protein marker based phylogenetic study is that, the non coding portions of the DNA are not involved in this process. It is already known that the percentage of non-genic portion is quite significant in comparison to gene bearing region within DNA [20]. So, interference of non-coding portion of DNA is totally nullified during the analysis of phylogenetic relation of Solanum plants based on poly peptides or protein through SDS-PAGE. Thus, this study has close resemblance with DNA marker based phylogenetic study to some extent.

Seed protein profile obtained by SDS-PAGE has been successfully employed to resolve the taxonomic disputes of different medicinally important non-tuberous species of Solanum. Variation in the major polypeptide profile indicates substantial differences in amino acid composition and represents genetic differences among the species [21]. In the past, taxonomic position of S. nigrum, $S$. villosum and $S$. americanum remained highly paradoxical and controversial. Clarke [22] did not separate them and considered all of the three species as Solanum nigrum. Hawkes and Edmonds [23] gave the rank of subspecies to $S$. villosum; and $S$. americanum was totally overlooked by him. While Edmonds and Chweya [7] gave separate rank to all of these three species. Morphologically these three species exhibit marked similarity.

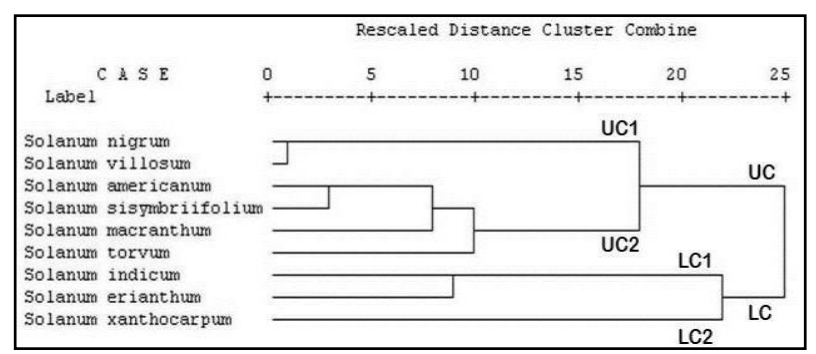

Figure 2. Dendrogram showing genetic relationship among nine selected species of Solanum based on SDS-PAGE seed protein profiling

The status of taxa has been justified by protein profile analysis [24]. In the present investigation, clear differentiation among $S$. nigrum, $S$. americanum and $S$. villosum has been revealed in the SDS-PAGE seed protein profiles (Figure 1). It is detected from the similarity indices (Table 3 ) that $S$. villosum is more closely (91\%) related to $S$. nigrum as compared to $S$. americanum. Thus, inter-similarity between $S$. americanum with $S$. nigrum is $60 \%$ and that of S. americanum and S. villosum is $73 \%$. These values of similarity indices based on seed protein profile favour the status of species for $S$. nigrum and $S$. americanum. These findings are directly reflected also in the dendrogram, where $S$. nigrum and $S$. villosum exhibit a high similarity and thus placed in the same cluster UC1 (Figure 2). The clustering of these species indicates a close evolutionary relationship and suggests the common origin of the two taxa. This assumption of common origin is already confirmed and supported by several workers [25,26], using different numerical analysis. From the dendrogram it is also clearly evident that $S$. villosum gets separated from $S$. nigrum only at the $3.6 \%$ of segregating distance (Figure 2). This distance may be revealed to consider S. villosum as the sub-species of S. nigrum. Thus, our results are in accordance to Hawkes and Edmonds [23], Baytop [27] and Yousaf et al. [28] but contrary to Edmonds and Chweya [7], Edmonds and Glidewell [29] and Nasir [30].

Based on seed protein analysis D'Arcy [31] placed $S$. sisymbriifolium and $S$. torvum in sections Cryptocarpum and Torva respectively and were located on separate branches of the UPGMA dendrogram. Our results also corroborate with Karihaloo et al. [32], where similarity between S. sisymbriffolium and S. torvum is $57 \%$ and occupy same cluster UC2 (Figure 2) and get separated from S. torvum at the $29 \%$ of segregating distance on dendrogram. Whalen [33] treated S. sisymbriifolium as one of the "unusual species" since it could not be accommodated in any of the groups. But our result is totally contrasted with his view. Though in the present study $S$. sisymbriifolium shows no similarity with $S$. erianthum and $S$. xanthocarpum but maintain moderate similarity $(33 \%-75 \%)$ with rest of the selected species and showing highest similarity $(75 \%)$ with $S$. americanum based on seed protein profile study. Although there may be lots of morphological distinctions present between $S$. sisymbriifolium and $S$. americanum; they become very close to each other based on this molecular marker and get separated only by $11 \%$ segregating distance on dendrogram (Figure 2). Therefore, sometimes molecular marker exhibits more pronounced effects than conventional morphological characters.

S. macranthum, the giant potato tree or giant star potato is a tropical, perennial, large, woody, bushy shrub that can grow into a medium-sized tree, which bears beautifully stunning flowers throughout the year. This plant exhibits distinct morphological similarity with $S$. torvum, which is also a perennial, woody shrub of comparatively small 
height $(2-3 \mathrm{~m})$. These two species show $25 \%$ similarity (Table 3) in their seed protein profiles and have been placed within same cluster UC2 and get separated $40 \%$ from each other on dendrogram (Figure 2).

$S$. erianthum is medicinally important plant, contains steroidal saponins and free genins as well as steroidal alkaloids of the spirosolane group [34]. This species has quite morphological resemblance with $S$. indicum. The resemblance is due to same life form, simple, ovate-elliptical, slightly wavy, densely wooly hairy, acute leaves, globose berry etc. This morphological similarity is reflected in our results, which shows $28 \%$ similarity (Table 3 ) based on seed protein profile and placed within same cluster LC1 (Figure 2).

S. xanthocarpum or yellow berried nightshade is a road side, medicinally important, perennial, prostrate herb with scattered stellate hairs and zigzag branched with prickly stem, showing morphologically distinctive features than rest of the selected species of Solanum. In the past the nomenclature of $S$. xanthocapum remained controversial. Burmanii [35] described this plant first and gave the name of the plant as $S$. surattense. Later various names have been given by several taxonomist of different era. Schard and Wendelbo gave the most accepted and commonly used synonym of $S$. surattense as $S$. xanthocarpum [36]. Phenotypically this species is highly polymorphic $[2,9,10,36]$. Therefore, a great deal of taxonomic confusion exists in this species. In our study, most remarkable observation is that, the SDS-PAGE protein profile of this particular species exhibited 2-3 polypeptide bands of comparatively lower molecular weight out of 6 bands found in the other studied species of Solanum (Table 2; Figure 1). From this protein profile study of $S$. xanthocarpum it could be assumed that, this species may possess many genes of short nucleotide length, which supports its uniqueness and shows no similarity with majority of the species of Solanum. Thus, on dendrogram only this species remains isolated and placed in LC2 cluster (Figure 2).

Based on the electrophoresis results, it may be suggested that the selected species of Solanum can be divided into two sub-genera A and B. Sub-genus B comprises of $S$. indicum, S. erianthum and S. xanthocarpum and sub-genus A comprises of rest of the selected species of Solanum (Table 4). Therefore, this lower order taxonomy of Solanum genus is different from conventional classification.

Table 4. Proposed classification of medicinally important selected species of the genus Solanum, based on seed protein profile

\begin{tabular}{|lcl|}
\hline Genus & Sub genus & \multicolumn{1}{c|}{ Species } \\
\hline Solanum & A & $\begin{array}{l}\text { S. nigrum, subsp. S. villosum, } \\
\text { S. americanum, S. sisymbriifolium, } \\
\text { S. macranthum, S. torvum } \\
\text { S. indicum, S. erianthum, } \\
\text { S.xanthocarpum }\end{array}$ \\
\hline
\end{tabular}

\section{Conclusions}

The taxonomy of Solanum is addressed by momentous changes, which can be attributed to the advent of molecular genetic techniques together with the combination of various biochemical and morphometric parameters. The evolving view about this diverse genus will lead to significant changes in phylogenetics. Thus, the concept of species complex (various morpho and cytotypes existing in the populations of the same species) described in Solanum nigrum for quite a long time has now been changed and presently three species have been described based on their diversified characteristics ( $S$. nigrum, S. villosum and $S$. americanum). Therefore, understanding the relationship in this genus, which is such a paradox of uniformity and hyper diversity, will have repercussions for other genera. The SDS-PAGE study based on seed protein profiles is a powerful tool to achieve a clear understanding of the molecular systematics as well as the correct identification of genotypes. This investigation has provided new information and reinforced suggestions made in previous phylogenetic studies, which were not the last word regarding evolutionary relationships within Solanum.

\section{Acknowledgements}

The first author gratefully acknowledges the UGC-SAP (DRS) and DST-FIST supported Department of Botany, Visva-Bharati for providing laboratory space and instrument facilities.

\section{REFERENCES}

[1] R. G. Olmstead, L. Bohs. A summary of molecular systematic research in the Solanaceae: 1982- 2006, Acta Horticulturae, Vol.745, 255-268, 2007. Online Available from https://doi.org/10.17660/ActaHortic.2007.745.11

[2] A. Paul. 2018. Morphological, Chromosomal, Biochemical and in vitro studies of some species of Solanum, Ph.D. thesis, Visva-Bharati University, West Bengal, India, Shodhganga. inflibnet, 2018. Online Available from http://hdl.handle.net/ $10603 / 221609$

[3] K. Zahara, N. Khmad, Y. Bibi, F. Biby, H. M. Hadaf, N. Sardar. An insight to therapeutic potential and phytochemical profile of Solanum villosum (L), Medicine in Drug Discovery, Vol.2, 1-6, 2019. Online Available from https://doi.org/10.1016/j.medidd.2019.100007

[4] R. Saijo, K. Murakami, T. Nohara, A. Tomimatsu, A. Sato, K. Matsuoka. Studies on the constituents of Solanum plants. II. On the constituents of the Immature Berries of Solanum nigrum L., Yakugaku Zasshi, Vol.102, No.3, 300-305, 1982. Online Available from https://doi.org/10.1248/yakushi1947 .102.3_300 
[5] M. S. Akhtar, M. Muhammad. Evaluation of the gastric antiulcerogenic effects of Solanum species of economic importance, Annals of the Missouri Botanical Garden, Vol.75, No.3, 8, 1989.

[6] E. E. Schilling, Q. S. Ma, R. N. Anderson. Common names and species identification in black nightshades, Solanum section Solanum (Solanaceae), Economic Botany, Vol.46, 223-225, 1992. Online Available from https://doi.org/10.10 07/BF02930641

[7] J. M. Edmonds, J. A. Chweya. Black nightshades: Solanum nigrum L. and related species, International Plant Genetic Resources Institute, Rome, Vol.15, 1-115, 1997. Online Available from http://edepot.wur.nl/195755

[8] M. L. K. Manoko, R. G. Van den Berg, R. M. C. Feron, G. M. Van der Weerden, C. Mariai. AFLP markers support separation of Solanum nodiflorum from Solanum americanum sensu stricto (Solanaceae), Plant Systematic Evolution, Vol.267, 1-11, 2007. Online Available from https://doi.org/10.1007/s00606-007-0531-4

[9] A. Paul, N. Banerjee. Phylogenetic diversity and relationships of some medicinally important species of Solanum as revealed by seed morphometric and biochemical analysis, International Journal of Advanced Research, Vol.3, No.7, 1403-1409, 2015. Online Available from http://www.journalijar.com/uploads/130_IJAR-6530

[10] A. Paul, N. Banerjee. Phylogenetic relationship of some species of Solanum based on morphological, biochemical and cytological parameters, Indian Journal of Fundamental and Applied Life Sciences, Vol.5, No.3, 51-56, 2015. Online Available from http://www.cibtech.org/Jls.htm

[11] T. L. Weese, L. Bohs. A three-gene phylogenetic of the gene Solanum (Solanaceae), Systematic Botany, Vol.32, No.2, 445-463, 2007. Online Available from https://doi.org/10.1600/036364407781179671

[12] P. Poczai, J. Taller, I. Szabo. Analysis of phylogenetic relationship in the genus Solanum (Solanaceae) as revealed by RAPD markers, Plant Systematics and Evolution, Vol.275, 59-67, 2008. Online Available from https://doi.org/10.1007/s00606-008-0051-x

[13] K. E. Roe. A revision of Solanum section Brevantherum (Solanaceae), Britonia, Vol.24, 239-278, 1972.

[14] R. N. Lester, S. M. Z. Hasan. Origin and domestication of the brianjal egg-plant, Solanum melongena, from $S$. incanum, in Africa and Asia, In: Solanaceae III: taxonomy, chemistry, evolution, J. G. Hawkes, R. N. Lester, M. Nees, N. Estrada. Eds., Royal Botanic Gardens, Kew, pp.369-387, 1991.

[15] D. J. Crawford. Plant Molecular Systematics Macromolecular Approaches, John Wiley and sons, New York, pp.26-27, 1990.

[16] M. M. Bradford. A rapid and sensitive method for the quantitation of microgram quantities of protein utilizing the principle of protein-dye binding, Analytical Biochemistry, Vol.72, 248-254, 1976. Online Available from https://doi.org/10.1016/0003-2697(76)90527-3

[17] V. K. Laemmli. Cleavage of structural proteins during the assembly of the head of bacteriophage T4, Nature, Vol.227, 680-687, 1970. Online Available from https://doi.org/10.10 $38 / 227680 \mathrm{a} 0$
[18] J. M. Edmonds. A synopsis of the taxonomy of Solanum sect. Solanum (Maurella) in South America, Kew Bulletin, Vol.27, No.1, 95-114, 1972. Online Available from https://doi.org/ 10.2307/4117874

[19] J. M. Edmonds. Taxonomic studies of Solanum sect. Solanum (Maurella). Botanical Journal of the Linnean Society, Vol.75, No.2, 141-178, 1977. Online Available from https://doi.org/ 10.1111/j.1095-8339.1977.tb01482.x

[20] E. Pennisi. Genomics: Encode project writes eulogy for junk DNA, Science, Vol. 337, No.6099, 1159-1161, 2012. Online Available from http://doi:10.1126/science.337.6099. 1159

[21] W. W. De Jong, A. Zweers, L. H. Cohen. Influence of single amino acid substitutions or deletions on electrophoretic mobility of sodium dodecyl sulfate-protein complexes, Biochemical and Biophysical Research Communications, Vol.82, No.2, 532-539, 1978. Online Available from https://doi.org/10.1016/0006-291x(78)90907-5

[22] C. B. Clarke. Solanaceae, In: Flora of British India, H. D. Hooker, C. B. Kcsi. Eds., Vol. IV, New Connaught Place, London, pp.229-237, 1885.

[23] J. D. Hawkes, J. M. Edmonds. Solanaceae, In: Flora Europea, V. H. Woody, N. A. Burges, D. M. Moore, D. H. Valentine, S. M. Walters, D. A. Webb. Eds., Cambridge University Press, Cambridge, pp.193-201, 1972.

[24] M. A. Khan. Seed protein electrophoretic pattern in Brachypodium P. Beavu. Species, Annals of Botany, Vol.70, 61-68, 1992. Online Available from http://www.jstor.org/st able/42764460

[25] C. B. Heiser, J. Soria, D. L. Burton. A numerical taxonomic study of Solanum species and hybrids, The American Naturalist, Vol.99, No.909, 471-488, 1965. Online Available from https://doi.org/ 10.1086/282392

[26] E. E. Schilling Jr., C. B. Heiser Jr. Re-examination of a numerical taxonomic study of Solanum species and hybrids, Taxon, Vol.25, No.4, 451-462, 1976. Online Available from https://doi.org/10.2307/1220527

[27] A. Baytop. Solanaceae, In: Flora of Turkey and the East Aegean Island, P. H. Davis. Ed., University Press, Edingburgh, Vol.6, pp.437-458, 1978. Online Available from https://www.jstor.org/stable/10.3366/j.ctvxcrg60

[28] Z. Yousaf, S. Masood, Z. K. Shinwari, M. A. Khan, A. Rabani. Evaluation of taxonomic status of medicinal species of the genus Hyoscyamus, Withania, Atropa and Datura based on PAGE, Pakistan Journal of Botany, Vol.40, No.6, 2289-2297, 2008

[29] J. W. Edmonds, S. M. Glidewell. Acrylamide gel electrophoresis of seed proteins from some Solanum (sec Solanum) species, Plant Systematics Evolution, Vol.127, No.4, 277-291, 1977. Online Available from https://doi.org/10.1007/BF00985991

[30] J. Y. Nasir. Solanaceae, In: Flora of Pakistan, S. I. Ali, E. Nasir. Eds., Pakistan Agricultural Research council, Islamabad, Fascicle, Vol.168, pp.1-61, 1985.

[31] W. G. D’Arcy. Solanaceae studies II: Typification of subdivisions of Solanum, Annals of the Missouri Botanical Garden, Vol.59, No.2, 260-278, 1972. Online Available 
from http://doi.org/10.2307/2394758

[32] J. L. Kahihaloo, M. Kaur, S. Singh. Seed protein diversity in Solanum melongena L. and its wild and woody relatives, Genetic Resources and Crop Evalution, Vol.49, No.6, 533-539, 2002. Online Available from http://doi.org/10.102 3/A.1021288108928

[33] M. D. Whalen. Conspectus of species groups in Solanum subgenus Leptostemonum, Gente Herbarum, Vol.12, No.4, 179-282, 1984.
[34] K. E. Roe. Solanum verbascifolium L., Misidentification and Misapplication, Taxon, Vol.17, No.2, 176-179, 1968. Online Available from https://doi.org/10.2307/1216510

[35] N. L. Burmanii. Flora Indica, Cornelius Haek, Leiden, Johannes Schreud, Amsterdam, pp. 57, 1768.

[36] Z. Yousaf, Z. K. Shinwari, M. A. Khan. Phenetic analysis of medicinally important species of the genus Solanum from Pakistan, Pakistan Journal of Botany, Vol.42, No.3, 1827-1833, 2010. 